University of Nebraska - Lincoln

DigitalCommons@University of Nebraska - Lincoln

April 1976

\title{
Relationship Between Physiological and Morphological Characteristics and Yield of Nondormant Alfalfa Clones
}

A. L. Foutz

Wallace Wilhelm

University of Nebraska-Lincoln, wwilhelm1@unl.edu

A. K. Dobrenz

Follow this and additional works at: https://digitalcommons.unl.edu/usdaarsfacpub

Part of the Agricultural Science Commons

Foutz, A. L.; Wilhelm, Wallace; and Dobrenz, A. K., "Relationship Between Physiological and Morphological Characteristics and Yield of Nondormant Alfalfa Clones" (1976). Publications from USDA-ARS / UNL Faculty. 132.

https://digitalcommons.unl.edu/usdaarsfacpub/132

This Article is brought to you for free and open access by the U.S. Department of Agriculture: Agricultural Research Service, Lincoln, Nebraska at DigitalCommons@University of Nebraska - Lincoln. It has been accepted for inclusion in Publications from USDA-ARS / UNL Faculty by an authorized administrator of DigitalCommons@University of Nebraska - Lincoln. 


\title{
Relationship Between Physiological and Morphological Characteristics and Yield of Nondormant Alfalfa Clones ${ }^{1}$
}

\author{
A. L. Foutz, W. W. Wilhelm, and A. K. Dobrenz ${ }^{2}$
}

\begin{abstract}
ABSTR ACT
Alfalfa (Medicago sativa L.) breeders are constantly striving to improve the productivity of alfalfa. Yields have been increased primarily through the selection of plant materials resistant to insects and diseases. The objective of this study was to evaluate physiological characteristics which might be used as selection criteria in alfalfa improvement. Alfalfa clones were grown under field conditions on a Mojave clay loam soil. Carbon dioxide flux was evaluated in a closed system using an infrared gas analyzer. The physiological variables measured in these studies did not account for the variation in yield among the clones. Apparent photosynthetic rates, dark respiration rates, and postillumination $\mathrm{CO}_{2}$ burst rates expressed as $\mathrm{mg} \mathrm{CO} \mathrm{dm}^{-2}$ hour $^{-1}$ were not correlated with dry matter production. However, when these physiological factors were multiplied by leaf area and expressed as total $\mathrm{CO}_{2}$ exchange per plant per hour, there was a significant relationship between yield and these calculated variables, in both studies. Regression analyses of more than 30 factors indicated that leaf area, leaf to stem-petiole ratio, and leaf weight per plant accounted for more than $95 \%$ of the variation in yield among alfalfa clones. The data from these studies suggest that morphological factors were more reliable indicators of alfalfa productivity than physiological factors.
\end{abstract}

Additional index words: Photosynthesis, Respiration, Leaf Area, Leaflet to stem-petioles ratio, Leaflet weight.

$Y^{1}$ IELD is a function of the quantity of the photosynthetic products available for plant growth (11). However, little evidence exists that photosynthetic rates per unit leaf area are correlated with yield of individual genotypes within the same species. Cultivars may have high potential photosynthetic activity per unit leaf area and yet not produce a high yield because of genetic or environmental factors which

\footnotetext{
${ }^{1}$ Contribution from the Dep. of Agronomy and Plant Genetics, Univ. of Arizona, Tucson. This paper is part of a Ph.D. dissertation submitted by the senior author in partial fulfillment of the requirements for the Ph.D. degree. Arizona Agriculture Exp. Stn. journal paper no. 2480. Received 7 July 1975.

${ }^{2}$ Former graduate research associate (now assistant professor of crop science, California Polytechnic State Univ., San Luis Obispo, CA 93407); former graduate research assistant (now graduate assistant, Dep. of Agronomy, Univ. of Missouri, Columbia, MO 65201), and professor, Dep. of Agronomy and Plant Genetics, Univ. of Arizona, Tucson, AZ 85721.
}

would limit the utilization of this potential. Heichel and Musgrave (9) observed differences in mean photosynthetic rates of 100 and $200 \%$ among several inbred lines and open pollinated cultivars of maize (Zea mays L.). Carlson et al. (2) suggested that differences in photosynthetic rates in alfalfa (Medicago sativa L.) were heritable and increased yields could be obtained by selection for increased photosynthetic potential. Yoshida (15) suggested that dry matter production of a single plant must be correlated with the product of leaf area and photosynthetic rate. Delaney and Dobrenz (4) found that dry matter forage yield of a single alfalfa plant was significantly correlated with the product of apparent photosynthesis and leaf area per plant. Several researchers $(5,7,11)$ found that dry matter production was dependent on leaf area rather than photosynthetic rate.

Alberta (1) indicated that respiration was an important factor which contributed to the dry matter production of closed canopies, but that it had received far less attention than photosynthesis. Ishizuka (10) suggested that a simple way to obtain higher yields would be to lower respiration as much as possible. However, Delaney and Dobrenz (4) found that dark respiration rates per unit leaf area were not significantly associated with dry matter production in alfalfa.

Decker (3) first demonstrated photorespiration in 1955 as a post-illumination burst of $\mathrm{CO}_{2}$. Since then many researchers $(12,14,16)$ have studied photorespiration and noted considerable variation in photorespiratory rates among species. Zelitch (17), Zelitch and Day (18), and Wilson (14) suggested that net photosynthesis was decreased in many plant species because of high rates of photorespiration. They concluded that increased $\mathrm{CO}_{2}$ uptake could be achieved by selection for plants with low photorespiratory rates.

Zelitch (17) noted that the carbon dioxide compensation point was a function of photorespiration. Decker (3) stated that net photosynthetic rate and photorespiratory rate measured by the $\mathrm{CO}_{2}$ compensation point was probably the most useful index of photosynthetic efficiency available to plant breeders. Heichel (8), on the other hand, suggested that the $\mathrm{CO}_{2}$ com- 
pensation point may not reflect respiratory activity. He concluded that $\mathrm{CO}_{2}$ compensation points would be of little value for screening inefficient species for lines low in photorespiration. Researchers $(6,14)$ have reported differences in $\mathrm{CO}_{2}$ compensation points among species of the genera Lolium, Triticum, and Aegilops. They concluded that the investigation of these genera for low $\mathrm{CO}_{2}$ compensation points would be valuable.

Photosynthesis by leaves accounts for most of the carbon dioxide incorporated into a plant. Researchers have, therefore, looked at leaf characteristics for a basis of selection of plants with high photosynthetic rates. Pearce et al. (13) and Carlson et al. (2) observed positive correlations between specific leaf weight and net photosynthesis. Differences in plant populations indicated that specific leaf weight was heritable and that there was a possibility of increased net photosynthesis in plants selected for high specific leaf weight. Delaney and Dobrenz (4) concluded that palisade tissue thick. ness of alfalfa leaflets could be used as selection criterion for photosynthetic potential.

The objectives of this research were to evaluate genotypic variation of several physiological and morphological factors among selected genotypes of alfalfa and to evaluate the relationship between the physiological factors, morphological factors, and yield in both space-planted and nonspace-planted studies.

\section{MATERIALS AND METHODS}

\section{Space-Planted Study}

Alfalfa clones in this study were selected from the 38 parental components of an experimental alfalfa, 'Reselect Sonora,' developed by Dr. M. H. Schonhorst at the Univ. of Arizona. Selection was based on dry matter production. Yields of the polycross progeny of the five clones when compared to the check cultivar 'Moapa' were 125, 125, 113, 103, and $101 \%$ for clones 22, 25, 39,3 , and 1 , respectively. One cutting from each of the five clones was space planted, 12 Aug. 1970 , on $81.4 \mathrm{~cm}$ centers in a randomized complete block design with 20 replications. The plot was located at the Tucson Plant Materials Center, Tucson, Ariz., on a Mojave clay loam soil.

\section{Nonspace-Planted Study}

Eleven alfalfa genotypes were selected from 59 clones of 'Mesa-Sirsa' alfalfa also provided by Dr. M. H. Schonhorst. The 11 clones were chosen on basis of differences in specific leaf weight (SLW). Stem cuttings were made and transplanted to the field at the Tucson Plant Materials Center in March 1972. Cuttings were transplanted in a randomized complete block design with 10 plants of each genotype in each of three replications. The plants were spaced on $20 \mathrm{~cm}$ centers to simulate the competition in a mature stand of alfalfa.

\section{Physiological Variables}

Apparent photosynthetic rates (AP), dark respiration (DR), post-illumination $\mathrm{CO}_{2}$ burst rates (PIB), and $\mathrm{CO}_{2}$ compensation points (CCP) were measured using a closed system. Six stems, $30-\mathrm{cm}$ long, were cut and placed in a $65-\mathrm{ml}$ vial of water in the evening from which each of the clones in three and four replications for the nonspace and space-planted studies, respectively. The stems were allowed to equilibrate in the dark until the following morning when the measurements were made. Five stems were used to determine $\mathrm{CO}_{2}$ competition points. The remaining stem was used to measure photosynthesis, dark respiration, and post-illumination $\mathbf{C O}_{2}$ burst rates.

The volume of the closed system was 1.1 liters. Air was curculated with a diaphragm pump at 6.9 liter $\mathrm{min}^{-1}$. The system was flushed with gas at ambient levels of $\mathrm{CO}_{2}$ of approximately $360 \mathrm{ppm}$, after the cut stem had been placed in the glass chamber. The chamber was then sealed and the air
Table 1. Means of morphological variables measured on five alfalfa clones in the space-planted study in 1972.

\begin{tabular}{rcccc}
\hline & \multicolumn{4}{c}{ Variable } \\
\cline { 2 - 5 } Clone & Yield & $\begin{array}{c}\text { Specific } \\
\text { leaf weight }\end{array}$ & $\begin{array}{c}\text { Leaflet:stem } \\
\text { petiole ratio }\end{array}$ & Leaf area \\
\hline & g/plant & $\mathrm{mg} / \mathrm{cm}^{2}$ & $\mathrm{~g} / \mathrm{g}$ & $\mathrm{dm}^{2} /$ plant \\
1 & $63 \mathrm{~b} *$ & $3.97 \mathrm{a}$ & $0.56 \mathrm{~cd}$ & $59 \mathrm{~cd}$ \\
3 & $33 \mathrm{c}$ & $3.75 \mathrm{~b}$ & $0.48 \mathrm{~d}$ & $32 \mathrm{~d}$ \\
22 & $127 \mathrm{a}$ & $3.32 \mathrm{~b}$ & $0.62 \mathrm{bc}$ & $154 \mathrm{a}$ \\
29 & $70 \mathrm{~b}$ & $3.63 \mathrm{~b}$ & $0.73 \mathrm{a}$ & $87 \mathrm{bc}$ \\
39 & $95 \mathrm{ab}$ & $3.44 \mathrm{~b}$ & $0.65 \mathrm{~b}$ & $110 \mathrm{~b}$ \\
\hline
\end{tabular}

* Means in the same column followed by the same letter are not significantly different at the 0.05 level according to Duncan's new multiple range test.

Table 2. Correlation coefficients between yield and several phy. siological and morphological variables of five alfalfa clones in the space-planted study in 1972.

\begin{tabular}{llc}
\hline \multicolumn{1}{c}{ Parameter } & & \multicolumn{1}{c}{$\mathrm{r}$} \\
\hline Apparent photosynthesis & $\left(\mathrm{mg} \mathrm{CO} \mathrm{Cm}^{-2} \mathrm{hour}^{-1}\right)$ & -0.05 \\
Dark respiration & $\left(\mathrm{mg} \mathrm{CO} 2 \mathrm{dm}^{-2} \mathrm{hour}^{-1}\right)$ & -0.42 \\
Post-illumination burst & $\left(\mathrm{mg} \mathrm{CO} \mathrm{dm}^{-2}\right.$ hour $\left.^{-1}\right)$ & -0.11 \\
Total apparent photosynthesis & $\left(\mathrm{mg} \mathrm{CO}_{2}\right.$ plant $^{-1}$ hour $\left.^{-1}\right)$ & $0.90 * *$ \\
Total dark respiration & $\left(\mathrm{mg} \mathrm{CO}_{2}\right.$ plant $^{-1}$ hour & \\
Total post-illumination burst & $\left(\mathrm{mg} \mathrm{CO}_{2}\right.$ plant $^{-1}$ hour & $0.64 * *$ \\
Leaf area & $\left(\mathrm{dm}^{2}\right)$ & $0.65 * *$ \\
Specific leaf weight & $\left(\mathrm{mg}^{2} / \mathrm{cm}^{2}\right)$ & $0.90 * *$ \\
Leaflet:stem petiole ratio & $(\mathrm{g} / \mathrm{g})$ & -0.22 \\
\hline
\end{tabular}

** Significant at the 0.01 level.

pumped out of the chamber through a drying column of 6 to 16 mesh moisture-indicating silica gel. A $250 \mathrm{ml}$ flask was inserted in the system to alleviate fluctuations in pressure before the gas entered the Beckman 215 Infrared Gas Analyser. The air was then reintroduced into the plant chamber. The change in $\mathrm{CO}_{2}$ concentration/unit time was monitored on a Beckman recorder. The light source was seven Sylvania 500 w flood lamps submerged in $15 \mathrm{~cm}$ of running water for temperature control. Photosynthesis measurements were made within a range of light intensity of $107.6 \mathrm{Klux}$ at the top of the stem to $43.0 \mathrm{Klux}$ at the base of the stem and at a temperature of $30 \pm 2 \mathrm{C}$. Measurements were made in a range of $\mathrm{CO}_{2}$ concentration of 360 to $280 \mathrm{ppm} \mathrm{CO}_{2}$.

Apparent photosynthesis, dark respiration, and post-illumination $\mathrm{CO}_{2}$ burst rates were calculated from the change in concentration of $\mathrm{CO}_{2}$ in $\mathrm{ppm} /$ unit time. These values were corrected for temperature and pressure, and expressed on a unit leaflet area and leaflet weight basis. Carbon exchange parameters were multiplied by the total leaf area/plant to generate total carbon exchange parameters/plant (TAP, TDR,TPIB).

\section{Morphological Variables}

Leaf area was determined with an air flow planimeter. Leaflets were dried at $80 \mathrm{C}$ for 24 hours and leaflet dry weight was used to calculate specific leaflet weight (SLW) (14). Five stems were selected from each experimental unit at each harvest and leaflets were separated from the petioles and stems. These components were dried at $80 \mathrm{C}$ for 24 hours, weighed, and used to determine leaflet to stem-petiole ratios $(\mathrm{L} / \mathrm{S})$. Yields on a per plant basis were determined on the same plants, and on the same dates that the physiological variables were evaluated. Leaflet area/plant (LA) was determined by dividing total leaf weight/plant (LW) by SLW.

\section{RESULTS}

\section{Morphological Variables}

Significant differences in dry matter production were noted among the five selections (Table 1) in the space-planted study. These data on dry matter production coincided with the data (personal communication, M. H. Schonhorst, Univ. of Arizona, 1970) on polycross progeny dry matter production used to select the five genotypes. Average dry matter produc- 
tion for clone 3 during the 1972 growing season was $33 \mathrm{~g} / \mathrm{plant} / \mathrm{harvest}$, whereas Clone 22 produced an average of $127 \mathrm{~g} /$ plant/harvest.

Specific leaf weight (SLW), leaflet area per plant (LA), and leaflet to stem-petiole ratio (L/S) were significantly different among the five clones used in the space-planted study (Table 1). The higher yielding clones exhibited greater $\mathrm{LA}$ and $\mathrm{L} / \mathrm{S}$ ratios than the lower yielding clones. Leaflet area per plant was highly correlated with dry matter production per plant $\left(\mathrm{r}=0.90^{* *} \text {; Table } 2\right)^{3}$

The results of the nonspace-planted study were very similar to the results obtained from the space-planted study. Dry matter production varied significantly among the 11 genotypes studied (Table 3). The average yield/harvest ranged from 224 to $79 \mathrm{~g}$ for clones 37 and 32 , respectively. Several of the morphological

$3 *$ indicates significance at the $1 \%$ level.

Table 3. Means of morphological variables measured on 11 alfalfa clones in the nonspace-planted study in 1972.

\begin{tabular}{rcccccc}
\hline Clone & Yield & Leaf area & Leaf wt. & \% leaves & $\begin{array}{l}\text { Leaflet:stem } \\
\text { Petiole ratio }\end{array}$ & $\begin{array}{l}\text { Specific } \\
\text { leaf wt. }\end{array}$ \\
\hline & g/plot & $\mathrm{dm}^{2} / \mathrm{plot}$ & $\mathrm{g} /$ plot & & $\mathrm{g} / \mathrm{g}$ & $\mathrm{mg} / \mathrm{cm}^{2}$ \\
4 & $114 \mathrm{ef} *$ & $138 \mathrm{bc}$ & $40 \mathrm{~cd}$ & $35.6 \mathrm{~cd}$ & $0.56 \mathrm{~cd}$ & $2.92 \mathrm{ab}$ \\
7 & $158 \mathrm{~cd}$ & $181 \mathrm{~b}$ & $58 \mathrm{~b}$ & $37.0 \mathrm{c}$ & $0.59 \mathrm{c}$ & $3.29 \mathrm{a}$ \\
8 & $128 \mathrm{de}$ & $153 \mathrm{bc}$ & $47 \mathrm{bc}$ & $37.0 \mathrm{c}$ & $0.59 \mathrm{c}$ & $3.11 \mathrm{a}$ \\
14 & $135 \mathrm{de}$ & $165 \mathrm{~b}$ & $47 \mathrm{bc}$ & $35.5 \mathrm{~cd}$ & $0.55 \mathrm{~cd}$ & $2.94 \mathrm{ab}$ \\
19 & $84 \mathrm{fg}$ & $167 \mathrm{~b}$ & $36 \mathrm{~cd}$ & $45.0 \mathrm{a}$ & $0.84 \mathrm{a}$ & $2.10 \mathrm{c}$ \\
27 & $198 \mathrm{ab}$ & $290 \mathrm{a}$ & $74 \mathrm{a}$ & $37.9 \mathrm{c}$ & $0.62 \mathrm{c}$ & $2.62 \mathrm{~b}$ \\
$\mathbf{3 1}$ & $117 \mathrm{ef}$ & $145 \mathrm{bc}$ & $38 \mathrm{~cd}$ & $34.0 \mathrm{~d}$ & $0.52 \mathrm{~d}$ & $2.62 \mathrm{~b}$ \\
32 & $79 \mathrm{~g}$ & $109 \mathrm{c}$ & $29 \mathrm{~d}$ & $37.2 \mathrm{c}$ & $0.60 \mathrm{c}$ & $2.73 \mathrm{~b}$ \\
37 & $\mathbf{2 2 4} \mathrm{a}$ & $252 \mathrm{a}$ & $80 \mathrm{a}$ & $36.4 \mathrm{~cd}$ & $0.58 \mathrm{~cd}$ & $3.26 \mathrm{a}$ \\
43 & $188 \mathrm{bc}$ & $270 \mathrm{a}$ & $77 \mathrm{~d}$ & $\mathbf{4 1 . 6 \mathrm { b }}$ & $0.72 \mathrm{~b}$ & $2.99 \mathrm{ab}$ \\
44 & $121 \mathrm{e}$ & $142 \mathrm{bc}$ & $43 \mathrm{c}$ & $\mathbf{3 6 . 4} \mathrm{cd}$ & $0.58 \mathrm{~cd}$ & $3.14 \mathrm{a}$ \\
\hline
\end{tabular}

* Means in the same column followed by the same letter are not significantly different at the 0.05 level according to Duncan's new multiple range test.

Table 4. Correlation coefficients between yield and several physiological and morphological variables measured on 11 alfalfa clones in the nonspace-planted study with a closed system in 1972.

\begin{tabular}{llc}
\hline \multicolumn{1}{c}{ Parameter } & $\mathrm{r}$ \\
\hline Apparent photosynthesis & $\left(\mathrm{mg} \mathrm{CO}_{2} \mathrm{dm}^{-2}\right.$ hour $\left.^{-1}\right)$ & 0.20 \\
Dark respiration & $\left(\mathrm{mg} \mathrm{CO}_{2} \mathrm{dm}^{-2}\right.$ hour $\left.^{-1}\right)$ & 0.18 \\
Post-illumination burst & $\left(\mathrm{mg} \mathrm{CO}_{2} \mathrm{dm}^{-2}\right.$ hour $\left.^{-1}\right)$ & 0.24 \\
Total apparent photosynthesis & $\left(\mathrm{mg} \mathrm{CO}_{2} \mathrm{plant}^{-1} \mathrm{hour}^{-1}\right)$ & $0.80^{* *}$ \\
Total dark respiration & $\left(\mathrm{mg} \mathrm{CO}_{2}\right.$ plant $^{-1}$ hour $\left.^{-1}\right)$ & $0.77 * *$ \\
Total post-illumination burst & $\left(\mathrm{mg} \mathrm{CO}_{2}\right.$ plant $^{-1}$ hour $\left.^{-1}\right)$ & $0.71^{* *}$ \\
Carbon dioxide compensation & & \\
$\quad$ point & $\left(\mathrm{ppm}^{2}\right)$ & -0.25 \\
Leaf area & $\left(\mathrm{dm}^{2}\right)$ & $-0.86^{* *}$ \\
Leaf weight & $(\mathrm{g})$ & $0.94 * *$ \\
Specific leaf weight & $(\mathrm{mg} / \mathrm{cm})$ & 0.19 \\
Leaflet:stem petiole ratio & $(\mathrm{g} / \mathrm{g})$ & -0.32 \\
\hline
\end{tabular}

** Significant at the 0.01 level. factors evaluated showed significant variation among the clones. Leaflet area, percent leaves, leaflet weight, and leaflet to stem-petiole ratio, all measurements of amount of leaf material/plant, differed significantly among the genotypes (Table 3). The higher yielding clones exhibited higher LA and LW values than the lower yielding clones. Correlation coefficients were $0.86^{* *}$ and $0.90^{* *}$ between yield and LA and LW, respectively (Table 4 ).

\section{Physiological Variables}

Differences in average apparent photosynthetic rates were detected among the five clones in the space-planted study during the 1972 growing season (Table 5). The lower producing selections, Clones 1 and 3 , exhibited higher photosynthetic rates, 23.3 and $28.6 \mathrm{mg}$ $\mathrm{CO}_{2} \mathrm{dm}^{-2}$ hour ${ }^{-1}$ respectively, than the higher yielding selections. However, $\mathrm{CO}_{2}$ uptake per unit leaf area was not correlated with yield (Table 2). These data are in agreement with those of Delaney and Dobrenz (4) who found that apparent photosynthesis expressed as mg $\mathrm{CO}_{2} \mathrm{dm}^{-2}$ hour $^{-1}$ was not related to yield of 13 'Mesa-Sirsa' clones.

Small differences were noted in dark respiration rates and post illumination $\mathrm{CO}_{2}$ burst rates, when expressed as $\mathrm{mg} \mathrm{CO}_{2} \mathrm{dm}^{-2}$ hour-1 among the five selections in the space-planted study (Table 5). Dark respiration rates and post-illumination $\mathrm{CO}_{2}$ burst rates were not correlated with dry matter production of the five selections (Table 2).

In the nonspace planted study, the carbon exchange rates evaluated (AP, DR, and PIB), varied significantly among the clones when expressed on a leaf area basis (Table 6), but were not related to yield (Table 4).

When carbon exchange rates were multiplied by the leaf area (LA) and expressed as total carbon exchange per plant (TAP, TDR, TPIB) there were significant differences among the genotypes in both space and nonspace-planted studies (Tables 5 and 6). The highest yielding plants incorporated more $\mathrm{CO}_{2}$ per plant than the lower yielding plants. Total apparent photosynthesis per plant was highly correlated with yield in the two studies $\left(\mathrm{r}=0.90^{* *}\right.$ and $\mathrm{r}=0.80^{* *}$, respectively Tables 2 and 4 ).

Significant differences in the amount of $\mathrm{CO}_{2}$ respired/plant in both dark (TDR) and light (TPIB) were found among the clones in both studies. Both these parameters were significantly correlated with yield in the space-planted $\left(\mathrm{r}=0.64^{* *}\right.$ and $\mathrm{r}=0.65^{* *}$, respectively) and nonspace-planted $\left(r=0.77^{* * *}\right.$ and $\mathrm{r}=0.71^{* *}$, respectively) studies.

Table 5. Means of physiological variables measured on five alfalfa clones in the space-planted study in a closed system in 1972.

\begin{tabular}{|c|c|c|c|c|c|c|}
\hline Clone & $\begin{array}{c}\text { Apparent } \\
\text { photosynthesis }\end{array}$ & $\begin{array}{c}\text { Dark } \\
\text { respiration }\end{array}$ & $\begin{array}{c}\text { Post-illumination } \\
\text { burst }\end{array}$ & $\begin{array}{l}\text { Total apparent } \\
\text { photosynthesis }\end{array}$ & $\begin{array}{l}\text { Total dark } \\
\text { respiration }\end{array}$ & $\begin{array}{c}\text { Total post- } \\
\text { illumination burst }\end{array}$ \\
\hline & \multicolumn{3}{|c|}{$\mathrm{mg} \mathrm{CO}_{2} \mathrm{dm}^{-2}$ hour $^{-1}$} & \multicolumn{3}{|c|}{$-\mathrm{mg} \mathrm{CO}_{2}$ plant $^{-1}$ hour $^{-1}$} \\
\hline $\begin{array}{r}1 \\
3 \\
22 \\
29 \\
39\end{array}$ & $\begin{array}{l}23.3 \mathrm{~b}^{*} \\
28.6 \mathrm{a} \\
21.2 \mathrm{bc} \\
18.1 \mathrm{c} \\
17.0 \mathrm{c}\end{array}$ & $\begin{array}{l}3.6 \mathrm{~b} \\
5.3 \mathrm{a} \\
3.3 \mathrm{~b} \\
3.4 \mathrm{~b} \\
3.7 \mathrm{~b}\end{array}$ & $\begin{array}{l}16.4 \mathrm{~b} \\
27.1 \mathrm{a} \\
20.1 \mathrm{~b} \\
14.7 \mathrm{~b} \\
17.1 \mathrm{~b}\end{array}$ & $\begin{array}{r}990 \mathrm{c} \\
1,022 \mathrm{~b} \\
2,673 \mathrm{a} \\
1,200 \mathrm{~b} \\
1,614 \mathrm{ab}\end{array}$ & $\begin{array}{l}161 \mathrm{~b} \\
143 \mathrm{~b} \\
403 \mathrm{a} \\
261 \mathrm{ab} \\
349 \mathrm{a}\end{array}$ & $\begin{array}{l}732 \mathrm{c} \\
716 \mathrm{c} \\
2,442 \mathrm{a} \\
1,041 \mathrm{bc} \\
1,708 \mathrm{a}\end{array}$ \\
\hline
\end{tabular}

* Means in the same column followed by the same letter are not significantly different at the 0.05 level according to Duncan's new multiple range test. 
Table 6. Means of physiological variables measured on 11 alfalfa clones in the nonspace-planted study with a closed system in 1972.

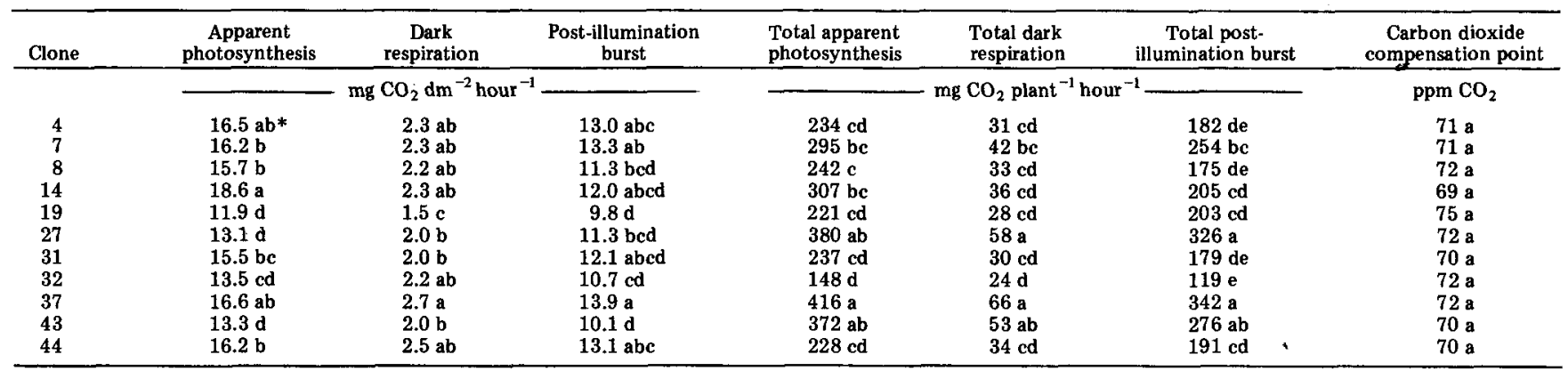

* Means in the same column followed by the same letter are not significantly different at the 0.05 level according to Duncan's new multiple range test.

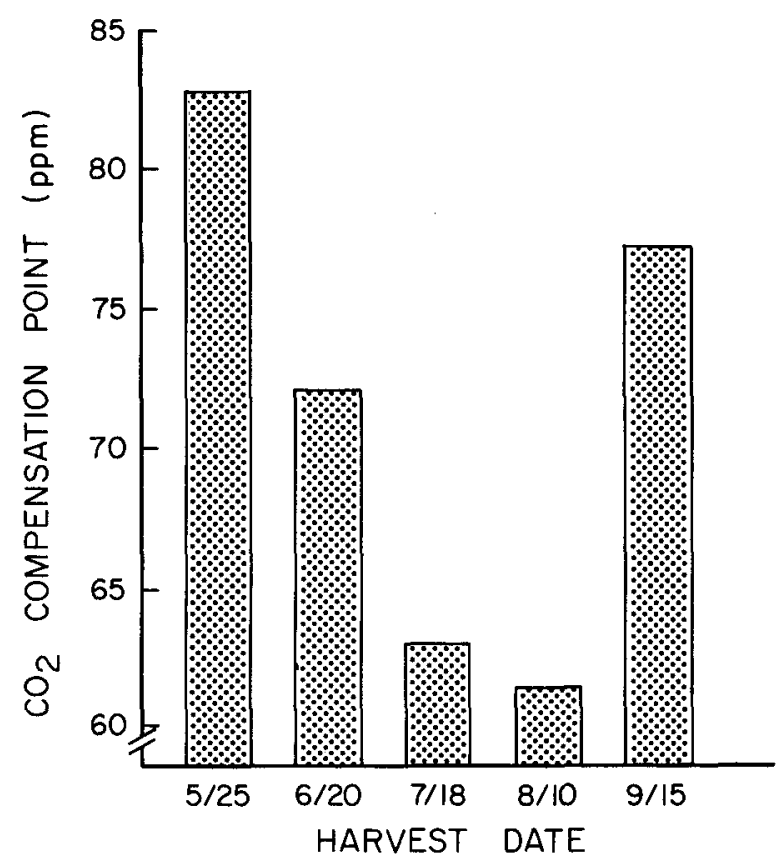

Fig. 1. Average $\mathrm{CO}_{2}$ compensation point (CCP) for 11 alfalfa genotypes harvested five times (month/day) in 1972.

Carbon dioxide compensation points were determined at each harvest date and the average for all genotypes was $71 \mathrm{ppm}$. No difference was found in the average CCP among genotypes (Table 6), however, the average CCP was significantly different among harvests. The CCP values declined from a high of 83 ppm at the first harvest to $60 \mathrm{ppm}$ at the fourth harvest and then increased to $77 \mathrm{ppm}$ at the fifth harvest (Fig. 1). This inverse relationship with mean air temperature at the individual harvest might be caused by the constant temperature used in measuring the CCP. As the daily mean temperature approached the temperature in the measuring chamber, the amount of photorespiration in comparison to photosynthesis was reduced and CCP declined.

Multiple regression analyses were made with all the physiological and morphological factors against yield. Only those variables which were significantly related to yield at the 0.05 level in the multiple regression analyses were entered into the regression equation. In the overall analysis $\mathrm{LA}+\mathrm{L} / \mathrm{S}+\mathrm{SLW}$ accounted for $96 \%$ of the variability associated with yield in the space-planted study. In the nonspace-planted study multiple regression analyses revealed that \% leaves, $\mathrm{LW}$, and $\mathrm{L} / \mathrm{S}$, accounted for more than $98 \%$ of the variation in yield.

\section{DISCUSSION AND SUMMARY}

Genotypic variation in the physiological factors existed when expressed on a leaf area basis. However, these factors were not correlated with dry matter production. A significant positive association was found when these factors were expressed on a rate/plant basis. Total $\mathrm{CO}_{2}$ exchange surface appeared to be more im. portant in determining yield than $\mathrm{CO}_{2}$ exchange/unit area. These data support the hypotheses of Yoshida (16) and Delaney and Dobrenz (4) that dry matter production of a single plant must be correlated with the product of leaf area and photosynthesis.

Morphological factors were more reliable indicators of alfalfa production than the physiological factors. The results of these studies indicated that plant selections should be based on morphological factors, along with desirable physiological characteristics, to develop high yielding alfalfa genotypes.

\section{LITERATURE CITED}

1. Alberta, T. 1970. The influence of carbohydrate reserves on respiration, photosynthesis, and dry matter production of intact plants. Int. Grassland Congr., Proc. 11 th (Queens. land, Australia). p. 517-522.

2. Carlson, G.E., R. H. Hart, C. H. Hanson, and R. B. Pearce. 1970. Overcoming barriers to higher forage yields through breeding for physiological and morphological characteristics. Int. Grassland Congr., Proc. 11th (Queensland, Australia). p. 248-251.

3. Decker, J. P. 1970. Photosynthetic efficiency, photorespiration and heterosis. Arizona State Univ. Bioeng. Bull. 12.

4. Delaney, R. H., and A. K. Dobrenz. 1974. Morphological and anatomical features of alfalfa leaves as related to $\mathrm{CO}_{2}$ exchange. Crop Sci. 14:444-447.

5. Duncan, W. G., and J. D. Hesketh. 1968. Net photosynthetic rates, relative leaf growth rates, and leaf number of 22 races of maize grown at eight temperatures. Crop Sci. 8:670-674.

6. Dvork, J, and L. Natr. 1971. Carbon dioxide compensation points of Triticum and Aegilops species. Photosynthetica $5: 1-5$.

7. Hanson, W. D. 1971. Selection for differential productivity among juvenile maize plants; associated net photosynthetic rate and leaf area changes. Crop Sci. 11:334-338.

8. Heichel, G. H. 1971. Response of respiration of tobacco leaves in light and darkness and the $\mathrm{CO}_{2}$ compensation concentration to prior illumination and oxygen. Plant Physiol. 48:178-182. 
9. - net photosynthesis of Zea mays L. Crop Sci. 9:483-486.

10. Ishizuka, Y. 1969. Engineering for higher yields. In J. D. Eastin et al. (eds). Physiological aspects of crop yield. Am. Soc. Agron. - Crop Sci. Soc. Am., Madison Wis.

11. Khan, M. A., and S. Tsunoda. 1970. Differences in leaf photosynthesis and leaf transpiration rates among six commercial wheat varieties of West Pakistan. Jap. J. Breeding. 20:344-350.

12. Ludwing, L. J, and D. T. Canvin. 1971. The rate of photorespiration during photosynthesis and the relationship of the substrate of light respiration to the products of photosynthesis in sunflower leaves. Plant Physiol. 48:712-719.

13. Pearce, R. B., G. E. Carlson, D. K. Barnes, R. H. Hart, and C. H. Hanson. 1969. Specific leaf weight and photosynthesis in alfalfa. Crop Sci. 9:423-426.

14. Wilson, D. 1972. Variation in photorespiration in Lolium. J. Exp. Bot. 23:517-524

15. Yoshida, S. 1972. Physiological aspects of grain yield. Ann. Rev. Plant Physiol. 23:437-464.

16. Zelitch, I. 1966. Increased rate of net photosynthetic carbon dioxide uptake caused by inhibition of glycolate oxidase. Plant Physiol. 41:1623-1631.

17. - - 1971. Photosynthesis, photorespiration, and plant productivity. Academic Press, Inc. New York.

18. - - , and P. R. Day. 1968. Variation in photorespiration. The effect of genetic differences in photorespiration on net photosynthesis in tobacco. Plant Physiol. 43:1838-1844. 